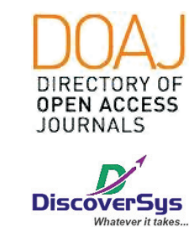

Published by DiscoverSys

\section{Pemberian antibiotik cefotaxime dengan konsentrasi sublethal pada isolat Klebsiella pnuemoniae yang resisten terhadap ampicilin menginduksi Multi Drug Resisten (MDR)}

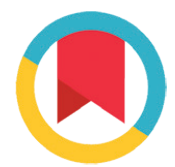

CrossMark

\author{
Gema Zakharian, ${ }^{1 *}$ Dewa Made Sukrama, ${ }^{2}$ Ni Nengah Dwi Fatmawati ${ }^{2}$
}

\section{ABSTRACT}

Background: Antibiotic resistance causes frequent infections to be difficult to treat and may aggravate the condition of infected patients which are requiring longer and more expensive antibiotic therapy. Klebsiella sp. is the most potential germ that causes nosocomial infections in the hospital. Klebsiella sp. which resulted a positive ESBL being perceived to directly exacerbate public health problems and become the center of attention in some countries, including Europe and America.

Methods: This study used 32 repetitions with Klebsiella pneumoniae isolate obtained from Clinical Microbiology Installation of Sanglah General Hospital. Isolate was divided into two groups, the first group was not given the treatment of cefotaxime with sublethal concentration and the second group was given the treatment of cefotaxime with sublethal concentration.

Resutls: The results of the treatment were tested by Pearson Chi Square method with the result that cefotaxime treatment with sublethal concentration significantly caused resistance to Klebsiella pneumoniae isolate and was proved by $p$ value of 0.014 ( $p<0.05$ ).

Conclusions: Antibiotic test results using Vitex found isolates Klebsiella pneumoniae are resistant to more than two antibiotics and isolates are also germs that have Extended Spectrum Beta-Lactamase (ESBL).

Keyword: Klebsiella pneumoniae, Antibiotic, Ampicillin, MDR, ESBLs, Cefotaxime

Cite This Article: Zakharian, G., Sukrama, D.M., Fatmawati, N.N.D. 2018. Pemberian antibiotik cefotaxime dengan konsentrasi sublethal pada isolat Klebsiella pnuemoniae yang resisten terhadap ampicilin menginduksi Multi Drug Resisten (MDR). Intisari Sains Medis 9(1): 64-70. DOI: 10.1556/ism.v9i1.166

\title{
ABSTRAK
}

Resistensi antibiotik menyebabkan infeksi yang sering terjadi menjadi sulit untuk diobati dan dapat memperburuk kondisi pasien yang terinfeksi sehingga memerlukan terapi antibiotik yang lebih lama dan lebih mahal. Klebsiella sp merupakan kuman yang paling potensial yang menyebabkan infeksi nosocomial di rumah sakit. Klebsiella sp yang menghasilkan ESBL positif dianggap dapat langsung memperburuk masalah kesehatan masyarakat dan menjadi pusat perhatian di beberapa negara di Eropa dan Amerika. Penelitian ini menggunakan pengulangan sebanyak 32 kali dengan isolat Klebsiella pneumoniae yang didapatkan dari Instalasi Mikrobiologi Klinis RSUP Sanglah. Isolat dibagi menjadi 2 kelompok, kelompok yang tidak diberikan treatment konsentrasi cefotaxime sublethal dan kelompok lain yang diberikan treatment konsentrasi cefotaxime sublethal. Dari hasil treatment diuji dengan metode Pearson Chi Square dengan mendapatkan hasil bahwa treatment cefotaxime dengan konsentrasi sublethal secara signifikan menyebabkan resistensi pada isolate Klebsiella pneumoniae dan dibuktikan dengan nilai $p$ sebesar $0,014(p<0,05)$. Dari hasil tes uji antibiotik dengang menggunakan Vitex didapatkan hasil isolat merupakan Klebsiella pneumoniae dan memiliki resistensi lebih dari dari dua antibiotik dan isolat juga merupakan kuman yang menghasilkan Extended Spectrum Beta-Lactamase (ESBL).
Kekhususan IImu Mikrobiolog Fakultas Kedokteran Universitas Udayana

2Departemen Mikrobiologi, Fakultas Kedokteran Universitas Udayana

${ }^{*}$ Correspondence to:

Gema Zakharian, Program Magister IImu Biomedik Kekhususan IImu Mikrobiologi Fakultas Kedokteran Universitas Udayana gemazakharian@gmail.com

Received: 2018-02-05

Accepted: 2018-02-19

Published: 2018-02-21
Kata Kunci: Klebsiella pneumoniae, Antibiotik, Ampicillin, MDR, ESBLs, Cefotaxime

Cite Pasal Ini: Zakharian, G., Sukrama, D.M., Fatmawati, N.N.D. 2018. Pemberian antibiotik cefotaxime dengan konsentrasi sublethal pada isolat Klebsiella pnuemoniae yang resisten terhadap ampicilin menginduksi Multi Drug Resisten (MDR). Intisari Sains Medis 9(1): 64-70. DOI: 10.1556/ism.v9i1.166

\section{PENDAHULUAN}

Resistensi antibiotik menyebabkan infeksi yang sering terjadi menjadi sulit untuk diobati dan dapat memperburuk kondisi pasien yang terinfeksi sehingga memerlukan terapi antibiotik yang lebih lama dan lebih mahal. Sudah banyak penelitian yang menemukan kuman yang resistan atau kebal terhadap antibiotik di seluruh dunia. Menurut National Institute of Allergy and Infectious Disease 
pada tahun 2011, penyebab resistensi antibiotik adalah mutasi genetik dan transfer genetika antar kuman, sehingga menjadi lebih kebal terhadap antibiotik. Beberapa faktor yang menyebabkan kuman resisten antibiotik antara lain adalah penggunaan antibiotik yang tidak sesuai dengan jangka terapi yang dianjurkan, diagnosis yang kurang tepat sehingga antibiotik yang diberikan kurang tepat. Dan meningkatnya penggunaan antibiotik di rumah sakit dan kecenderungan antibiotik dibeli bebas atau tanpa resep dokter. Hal ini didukung oleh penelitian yang dilakukan oleh Helmia tahun 2014.

Kuman patogen telah mampu mengembangkan sejumlah besar mekanisme untuk menghindari efek antibiotik dengan cara membentuk enzim yang dapat merusak antibiotik sampai pada kemampuannya untuk memodifikasi dari proses metaboliknya. Berbagai mekanisme yang baru dan lebih kompleks secara cepat dikembangkan mikroorganisme mengikuti diperkenalkannya dan digunakannya suatu antibiotik baru. Perubahan perubahan genetik menyebabkan terjadinya resistensi kuman mengkin terjadi melalui mutasi, seperti Multi Drug Resistance (MDR) dari Mycobacterium Tuberculosis dan resiten quinolon pada Enterobacteriaceae. Mekanisme genetik lain adalah transposon dan integron, yang memungkinkan gen pembawa plasmid menyatu kedalam kromosom bakteri, sehingga resistensi yang terjadi menetap dan diturunkan ke generasi bakteri berikutnya. ${ }^{1}$

Enterobacteriaceae merupakan salah satu bakteri gram negatif fakultatif yang biasanya banyak menginfeksi pasien rumah sakit. Biasanya kuman ini banyak yang sudah resiten terhadap antibiotik golongan beta-laktam. Hal ini kemungkinan disebabkan oleh banyak pasien rumah sakit yang mengkonsumsi antibiotik sebelum berkonsultasi dengan dokter sehingga penggunaan antibiotik yang tidak sesuai dapat mengakibatkan kuman resisten terhadap antibiotik. Resistensi ini memungkinkan peningkatan produksi enzim $\beta$-Lactamase oleh Enterobacteriaceae secara signifikan yang dapat menyebabkan kematian pasien. Sebagai contohnya, sebuah penelitian menyebutkan kematian pasien mencapai $60 \%$ dengan infeksi aliran darah oleh Enterobacteriaceae Extended Spectrum Beta Lactamase (ESBL) positif ketika tidak diberikan terapi antibiotik. ${ }^{2}$

Klebsiella sp. merupakan kuman yang paling potensial menyebabkan infeksi nosokomial di rumah sakit. Selain di rumah sakit, Klebsiella yang menghasilkan ESBL positif dianggap dapat langsung memperburuk masalah kesehatan masyarakat dan menjadi pusat perhatian di beberapa negara di
Eropa dan Amerika. Klebsiella pneumoniae lebih banyak ditemukan menyebabkan penyakit karena mempunyai dua tipe antigen pada permukaan selnya yaitu Antigen $\mathrm{O}$ yang merupakan lipopolisakarida yang terdapat dalam sembilan varietas, serta antigen K. Yang merupakan polisakarida yang dikelilingi oleh kapsula dengan lebih dari 80 varietas. Kedua antigen ini meningkatkan patogenitas Klebsiella pneumoniae. Selain itu, Klebsiella pneumoniae banyak ditemukan dapat memproduksi enzim ESBL (Extended Spectrum Beta Lactamase) yang dapat melumpuhkan kerja berbagai jenis antibiotik. $^{3}$

Extended-Spectrum Beta-Lactamses (ESBLs) merupakan enzim yang dapat menghidrolisis beta-lactam lebih baik dan lebih luas dibandingkan dengan resistensi antibiotik biasanya. ESBL ini mempunyai kemampuan untuk menginaktifkan antibiotik golongan beta-lactam termasuk golongan oxyimino seperti ceftazidiime, caftriaxone, cefotaxime dan golongan oxymino-monobactam seperti aztreonam. Namun ESBL tidak aktif menghadapi cephamycins dan carbapenems. Secara umum ESBL dapat menghambat beta-lactamase seperti cluvanalate dan tazobactam. Golongan ESBL CTX-M merupakan golongan yang paling banyak ditemukan dalam resistensi kuman. Di beri nama CTX-M karena mempunyai aktifitas untuk menghidrolisis beta-lactamases, termasuk cefotaxime. Enzim ini lebih menghidrolisis cephalothin daripada benzylpenicilin dan lebih mudah untuk menghidrolisis cefotaxime daripada ceftazidime. CTX-M lebih baik dalam menghambat dari tazobactam daripada sulbactam dan clavulanate. CTX-M ini juga sudah ada dalam plasmid bakteri Kluyvera species. Pada masa lampau, CTX-M banyak ditemukan pada Amerika selatan, China, dan Jepang. Namun beberapa penelitian terakhir, CTX-M juga ditemukan pada Eropa barat, Amerika utara, China, Jepang, dan India. Lebih dari 40 variasi dari CTX-M sudah diteliti di dunia dan banyak ditemukan pada Enterobacteriaceae dan juga Salmonela spp. ${ }^{4}$

Untuk di Indonesia sendiri, menurut penelitian yang dilakukan oleh Fatmawati tahun 2015 yang dilakukan di RSUP Sanglah Denpasar Bali, menunjukkan bahwa mayoritas Klebsiella pneumoniae yang menghasilkan ESBL yang terisolasi dari spesimen membawa gen TEM, SHV dan CTX-M secara bersama - sama. ${ }^{5}$

Menurut penelitian yang dilakukan oleh Lestari tahun 2009, kuman penghasil ESBLs didapatkan adanya penggunaan antibiotik golongan cephalosporin yang tidak terkontrol baik penulisan resep, dosis, frekuensi dan pemberian yang tidak tepat. ${ }^{6}$ 


\section{METODE PENELITIAN}

Penelitian dilakukan selama satu tahun pada Instalasi Mikrobiologi Klinis RSUP Sanglah Denpasar dan Laboratorium Mikrobiologi Fakultas Kedokteran Universitas Udayana Denpasar Bali. Sampel yang digunakan adalah 2 isolat bakteri Klebsiella pneumoniae yang memenuhi kriteria inklusi. Prosedur dalam penelitian ini terdiri dari, persiapan isolate, pembuatan media $\mathrm{MH}$ yang ditambahkan ampicillin, penentuan konsentrasi sublethal Cefotaxime, treatment dengan cefotaxime konsentrasi sublethal, dan observasi pertumbuhan. Data yang diperoleh, kemudian dianalisis menggunakan statistic deskriptif yang disajikan dalam bentuk tabel, gambar dan narasi.

\section{Persiapan isolate}

Isolat klinis Klebsiella pneumoniae yang didapatkan dari Instalasi Mikrobiologi Klinis RSUP Sanglah Denpasar kemudian ditanam pada media Mueller Hinton dan diinkubasi pada suhu $37^{\circ} \mathrm{C}$ selama $24 \mathrm{jam}$. Isolat Klebsiella pneumoniae yang tumbuh distok pada larutan PBS sebanyak 2 kali. Larutan PBS yang pertama disimpan di suhu $-20^{\circ} \mathrm{C}$ sebagai stok, dan larutan PBS kedua dilanjutkan untuk proses isolasi DNA dan dicek secara genotipnya. Larutan PBS yang kedua diboiling dengan suhu $100^{\circ} \mathrm{C}$ selama 10 menit, kemudian didinginkan dengan es selama 3 menit, dan disentrifuse 8000rpm selama 1 menit. Dari hasil sentifuse diambil supernatannya sebagai template DNA untuk proses selanjutanya. Template DNA diambil sebanyak $0,8 \mu \mathrm{l}$ ditambahkan dengan primer forward dan reverse SHV (Fà5'- CTTTACTCGCTTTATCG -'3 ; Rà5' TCCCGCAGATAAATCACCA -'3) sebanyak $0,2 \mu$, primer forward dan reverse CTXM (Fà5'- ATGTGCAGYACCAGTAARGT -'3; R - TGGGTRAARTARGTSACCAGA sebanyak $0,3 \mu \mathrm{l}$, ditambahkan master mix sebanyak $5 \mu \mathrm{l}$ dan ditambahkan $3,2 \mu \mathrm{ldd} \mathrm{H}_{2} \mathrm{O}$. kemudian sampel di PCR sebanyak 35 siklus dengan komposisi sesuai

2. Pembuatan media $\mathrm{MH}$ yang ditambahkan ampicillin

Media Meuller Hinton Agar (MHA) ditambahkan dengan Aquades dalam erlenmeyer kemudian diaduk didalam waterbath agar lebih cepat larut. Setelah media Mueller Hinton (MH) bubuk dengan aqudes tercampur sempurna kemudian ditempatkan dalam autoclaf untuk sterilisasi. Setelah sterilisasi dan dibiarkan sampai suhu menjadi hangat hangat kuku kemudian ditambahkan antibiotik ampicilin dengan konsentrasi $1 \mu \mathrm{g} / \mathrm{ml}$ sebagai seleksi pertumbuhan bakteri. Media $\mathrm{MH}+$ amp dituang ke cawan petri streil dibiarkan sampai memadat sempurna dan disimpan dalam kulkas untuk proses selanjutnya.

3. Penentuan konsentrasi sublethal cefotaxime Koloni tunggal kemudian ditumbuhkan pada media MHA + amp dan ditambahkan antibiotik Cefotaxime dengan beberapa gradien konsentrasi MIC yaitu 25\%, 50\%, 75\%, dan 100\% yang ditumbuhkan dalam inkubator dengan suhu $37^{\circ} \mathrm{C}$ selama 1 hari dan perlakuan ini dilakukan pengulangan sebanyak 6 kali. Setelah didapatkan hasil dari pertumbuhan koloni bakteri, maka akan di tentukan konsentrasi mana yang dipakai untuk perlakuan selanjutnya.

4. Treatment dengan cefotaxime konsentrasi sublethal

Dari data kesimpulan yang didapatkan pada metode 4, maka penelitian dilanjutkan kembali dengan treatment konsentrasi sublethal Cefotaxime yang setingkat lebih tinggi dari kadar MIC sebelumnya. Percobaan ini terus dilanjutkan dan diulang kembali sampai mencapai konsentrasi antibiotik Cefotaxime $100 \% \mathrm{MIC}(1 \mu \mathrm{g} / \mathrm{ml})$ atau lebih.

5. Observasi pertumbuhan

Dari 16 kali pengulangan dihitung beberapa banyak sampel yang tumbuh dengan treatment konsentrasi sublethal antibiotik Cefotaxime dan dibandingkan dengan pertumbuhan sampel tanpa treatment konsentrasi sublethal antibiotik Cefotaxime.

\section{HASIL}

Isolat Klebsiella pneumonia didapatkan dari Instalasi Mikrobioligi Klinik RSUP Sanglah Denpasar dari bulan Juli 2016 - Mei 2017 dan ditemukan sebanyak 14 sampel yang memenuhi kriteria inklusi dan eksklusi. Sampel terdiri dari 7 isolasi dari sampel sputum, 5 isolasi dari sampel urine, 1 isolasi dari sampel darah, 1 isolasi dari sampel lainnya dan ditambahkan 1 sampel Klebsiella pneumonia jenis ATCC yang biasa digunakan dalam penelitian (Gambar 1).

Isolat Klebsiella pneumonia didapatkan dari Instalasi Mikrobioligi Klinik RSUP Sanglah Denpasar dari bulan Juli 2016 - Mei 2017 dan ditemukan sebanyak 14 sampel yang memenuhi kriteria inklusi dan eksklusi. Sampel terdiri dari 7 isolasi dari sampel sputum, 5 isolasi dari sampel urine, 1 isolasi dari sampel darah, 1 isolasi dari sampel lainnya dan ditambahkan 1 sampel Klebsiella pneumonia jenis ATCC yang biasa digunakan dalam penelitian. PCR dengan menggunakan primer blaCTXM dan blaSHV dilakukan dengan suhu annealing sesuai dengan penelitian 


\section{Sputum $\square$ Urine Darah $\square$ Lain Lain}
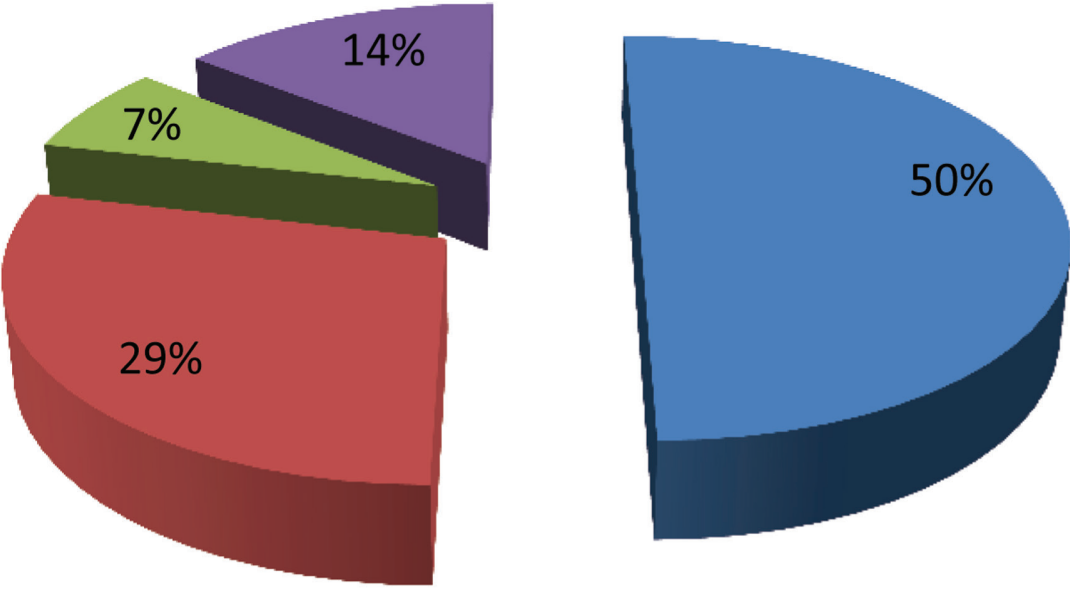

Gambar 1 Distribusi Isolat Klinik K. pneumoniae berdasarkan specimen

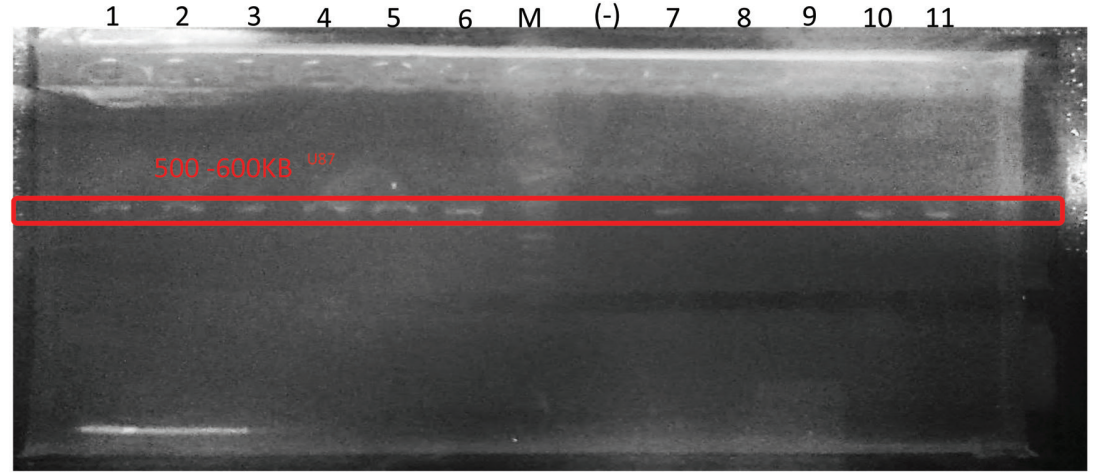

Gambar 2 Hasil PCR isolat K.pneumoniae dengan primer blaCTXM dan blaSHV yang di elektroforesi pada agarose $0,8 \%$ dan semua sampel terdapat band pada 500-600bp (kolom $1=\mathrm{U} 87,2=\mathrm{SP} 67$, 3=SP105, 4=SP102, 5=SP 57, 6=L120, M=Marker, (-)=control negative, $7=\mathrm{U} 231,8=\mathrm{SP} 31,9=\mathrm{D} 50,10=\mathrm{SP} 18,11=\mathrm{SP} 92)$

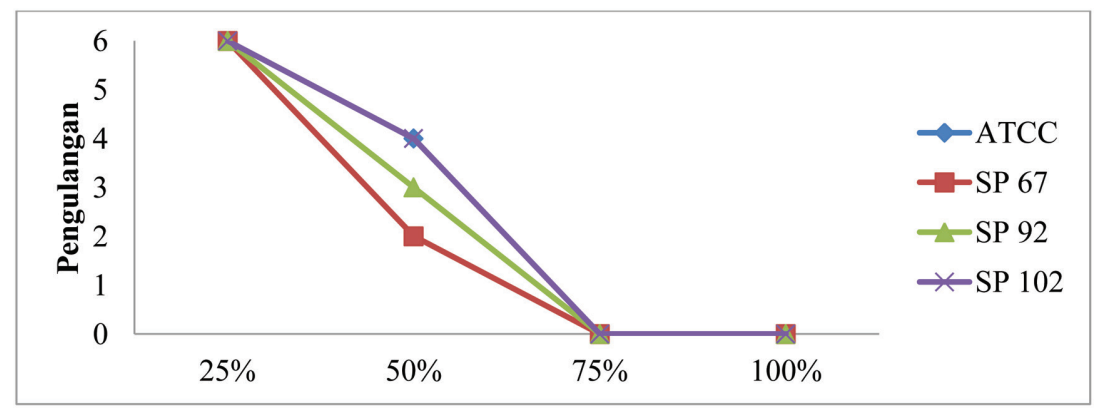

Grafik 1 Pertumbuhan Isolat K.pneumoniae Dengan Konsentrasi Sublethal Cefotaxime

sebelumnya untuk mendeteksi adanya gen CTXM dan SHV. Semua sampel secara genotip mempunyai gen CTXM yang seharusnya resisten terhadap antibiotik Cefotaxime, namun secara fenotip (dibuktikan dengan hasil Vitex) semua sampel hanya resisten terhadap antibiotik Ampicilin. Hasil
PCR untuk mendeteksi gen CTXM dapat dilihat dalam gambar 2

Mueller Hinton Agar (MHA) dipilih karena merupakan media yang paling cocok untuk menguji suseptibilitas atau sensitifitas bakteri dan mengandung starch yang berfungsi untuk menyerap racun yang dikeluarkan bakteri sehingga tidak mengganggu kinerja antibiotik dalam penelitian. Media Mueller Hinton (MH) di larutkan dalam aquades dan disterilisasi dengan autoclave kemudian ditambahkan antibiotik Ampicilin (Sigma) dengan konsentrasi $1 \mu \mathrm{g} / \mathrm{ml}$. Media dibiarkan menjadi padat dan disimpan dalam kulkas sebagai stok.

Penentuan konsentrasi sublethal antibiotik cefotaxime bertujuan untuk mengetahui konsentrasi yang sesuai untuk perlakuan treatment yang akan diteliti. Koloni tunggal sampel yang sudah diinkubasi diambil 1 koloni dan ditumbuhkan pada media MHA+Ampc yang ditambahkan antibiotik Cefotaxime dengan konsentrasi yang berbeda dan diulang 6 kali. Dari pengulangan didapatkan bahwa konsentrasi sublethal konsentrasi antibiotik cefotaxime pada konsentrasi 50\% MIC $(0,5 \mu \mathrm{g} / \mathrm{ml})$ pada grafik 1.

Isolat yang sesuai dengan kriteria kemudian ditreatment dengan konsentrasi sublethal 50\% dan $75 \%$ sesuai dengan percobaan sebelumnya. Koloni bakteri yang tumbuh yang tumbuh dari konsentrasi 50\% dan 75\% akan dipilih dan ditumbuhkan pada media pertumbuhan yang mengandung cefotaxime $100 \%$ MIC (1xMIC=dosis lethal). Hasil treatment dengan konsentrasi sublethal didapatkan bahwa dari 4 sampel yang di treatment Cefotaxime konsentrasi sublethal dengan 16 kali pengulangan sesuai dengan rumus Federer dan menunjukkan hasil yang dapat dilihat pada gambar 3 .

Pada Gambar 5 merupakan isolat Klebsiella pneumoniae yang ditreatment dengan antibiotik cefotaxime dengan konsentrasi 75\% MIC, dari penelitian didapatkan hasil sampel ATCC semua sampel tumbuh, sampel SP67 sebanyak 10 sampel tumbuh, SP92 semua sampel tumbuh, sampel SP102 sebanyak 14 sampel tumbuh. Kemudian dibandingkan dengan Gambar 5.9, dimana isolat Klebsiella pneumoniae yang tumbuh dari treatment menggunakan antibiotik cefotaxime dengan konsentrasi $75 \%$ MIC ditumbuhkan kembali pada media Mueller Hinton + ampicillin yang ditambahkan dengan antibiotik cefotaxime dengan konsentrasi $100 \%$. Dari perbandingan ini, sampel Klebsiella pneumoniae yang tidak tumbuh hanya pada 2 sampel SP67. Dari perbandingan Gambar 5.7 dan Gambar 5.9, dapat dilihat perbedaan sampel yang tumbuh yang di treatment dengan konsentrasi sublethal cefotaxime lebih banyak yang tumbuh jika dibandingkan dengan sampel yang tidak langsung ditreatment dengan cefotaxime konsentrasi 100\% MIC. 


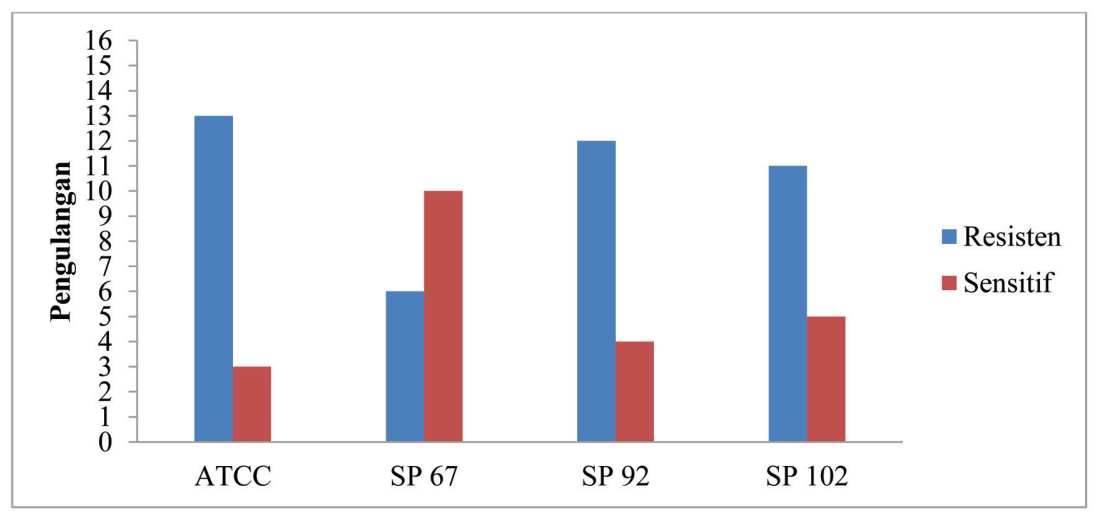

Gambar 3 Grafik Pertumbuhan Isolat Klebsiella pnuemoniae yang dengan Cefotaxime Konsentrasi 50\% MIC. Yang dipaparkan dengan Cefotaxime konsentrasi 100\% MIC

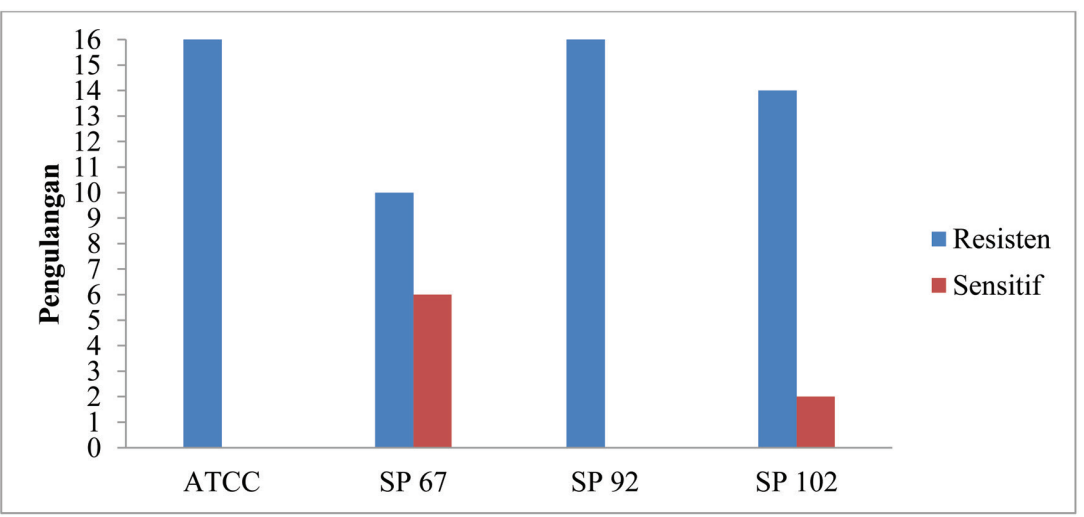

Gambar 4 Grafik Pertumbuhan Isolat Klebsiella pnuemoniae yang dengan Cefotaxime Konsentrasi 50\% MIC. Yang dipaparkan dengan Cefotaxime konsentrasi 75\% MIC

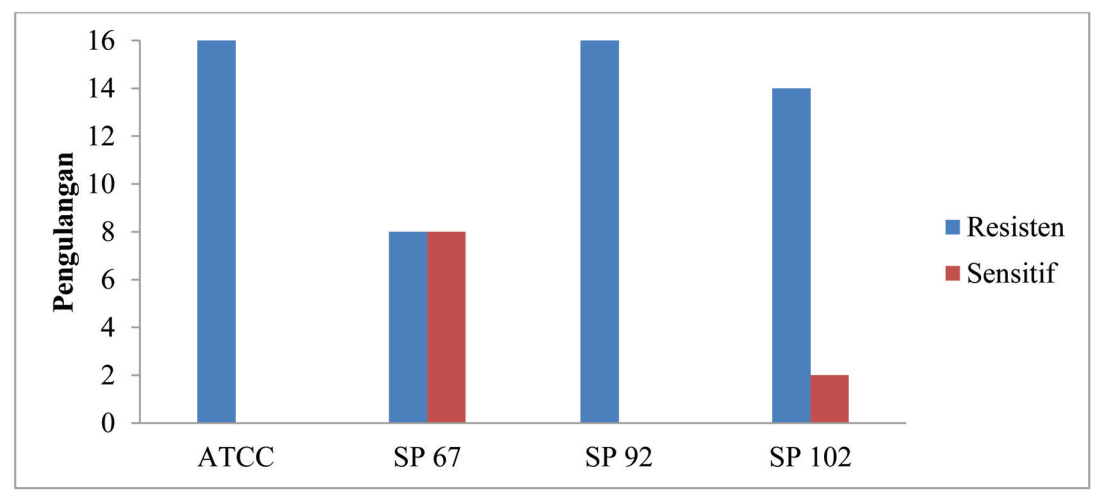

Gambar 5 Grafik Pertumbuhan Isolat Klebsiella pnuemoniae yang dengan Cefotaxime Konsentrasi 75\% MIC. Yang dipaparkan dengan Cefotaxime konsentrasi 100\% MIC

\section{PEMBAHASAN}

Dalam penelitian ini digunakan 2 jenis antibiotik yaitu ampicillin dan cefotaxime. Berdasarkan struktur kimianya, ampicillin merupakan golongan beta-laktam dimana memiliki mekanisme menghambat sintesis dan fungsi dinding sel (Tjay dan Rahardja, 2007). Ampicillin secara aktifitasnya memiliki spectrum luas (broad spectrum) dan sering digunakan untuk mengobati pasien infeksi yang belum diidentifikasi dengan pembiakan dan sensitivitas. $^{7}$

Cefotaxime merupakan antibiotik Cephalosporin golongan ketiga yang memiliki afinitas baik terhadap bakteri gram positif dan memiliki cakupan gram negatif yang lebih luas serta aktif melawan S.pneumoniae obat ini digunakan untuk mengobati berbagai macam infeksi berat yang disebabkan oleh organisme yang resisten terhadap kebanyakan antibiotik. Menurut penelitian yang dilakukan oleh Baharirama pada RSUD Buleleng tahun 2013, Cefotaxime merupakan antibiotik pilihan utama untuk pasien community acquired pneumonia anak di Rumah Sakit Umum Daerah Kabupaten Buleleng. ${ }^{8}$

Pada penelitian yang dilakukan Lestari tahun 2009, kuman penghasil ESBLs didapatkan adanya penggunaan cephalosporin yang tidak terkontrol baik penulisan resep, dosis, frekuensi dan pemberian yang tidak tepat. Dalam beberapa penelitian yang dilakukan menyebutkan bahwa penggunaan cefotaxime dengan konsentrasi sublethal dapat menginduksi terjadinya Extended Spectrum Beta Lactamase (ESBL) dan menjadi salah satu golongan ESBL yaitu CTXM. ${ }^{6}$

Setiap bakteri memiliki mekanisme yang berbeda dalam menimbulkan resitensi terhadap antibiotik. Klebsiella pneumoniae termasuk dalam salah satu dari Sembilan bakteri yang menjadi perhatian resistensi terhadap antibiotik. Transfer gen resisten merupakan salah satu mekanisme yang penting dalam penyebaran resistens antibiotik, terutama melalui plasmid, merupakan salah satu mekanisme yang penting dalam penyebaran resistensi antibiotik pada bakteri. Dalam mekanisme resitensi secara genotip ada beberapa cara antara lain:

\section{Mutasi Spontan}

Sifat resitensi terhadap antibiotik dapat disebabkan oleh mutasi genom pada bakteri. Mekanisme resistensi antibotik yang melibatkan berbagai mekanisme biokimiawi dibakteri dapat diterangkan dengan adanya mutasi pada gen yang mengkode salah satu komponen yang terlibat di dalam interaksi biokimiawi antara antibiotik dan bakteri. Mutasi yang terjadi pada gen yang mengkode target molekul dari antibiotik merupakan contoh dari mekansime ini. Resistensi terhadap quinolon terjadi karena mutasi pada gen gyrA dan parC. Resistensi $M$. tuberculosis terhadap rifampicin terjadi karena mutasi pada gen $r p o B$, sementara resistensi terhadap isoniazid disebabkan mutasi pada gena katG. Resistensi $H$. pylori terhadap amoxicillin berhubungan denganmutasi pada gen pbp1. ${ }^{9}$ 


\section{Hyper Mutation}

Model Hypermutable state menyatakan bahwa selama terjadi selective pressure yang berkepanjangan dengan kondisi yang nonlethal atau sublethal, sebagaian kecil koloni bakteri mengalami Hyper Mutation, dimana bakteri akan mengalami mutasi 10 kali bahkan 50-10.000 kali lebih sering dibandingkan dengan awalnya. Dalam hal ini pemakaian antibiotik dengan jangka waktu lama yang paling banyak menyebabkan Hyper Mutation. Hyper Mutation paling banyak ditemukan pada E. coli, S.enterica, Neisseria meningitides (N. meningitides), H. influenzae, S. aureus, Helicobacter pylori (H.pylori), Streptococcus pneumoniae (S.pneumoniae), dan P. aeruginosa.

\section{Mutagenesis Adaptif}

Proses mutasi yang sebagian besar terjadi pada sel yang sedang membelah dan terjadi kesalahan dalam mereplikasi DNA. Namun hal ini juga pula pada sel yang tidak sedang membelah atau membelah dengan lambat. Biasanya mutasi ini didukung oleh pemberian antibiotik dengan konsentrasi sublethal sebagai selective pressure. Contohnya pada pemberian kanamycin dan streptomycin pada E. Coli dapat menimbulkan mutagenesis adaptif yang berakibat pada restensi terhadap antibiotik tersebut. ${ }^{10}$

\section{Horizontal Gene Transfer}

Transfer gen dari satu bakteri ke bakteri lain disebut dengan Horizontal Gene Transfer. Beberapa mekanisme dari Horizontal Gene Transfer antara lain transfer resistensi melalui plasmid, transfer resistensi dari virus, dan transfer Free DNA. Gen dapat ditransfer dengan 3 cara yaitu: Transduksi ( melalui Bakteriofage dan intergron), Konjugasi (melalui plasmid dan kojugasi transposom), dan Transformasi ( melalui incorporation dari kromosom DNA dan dari plasmid kedalam DNA kromosom). Kebanyakan plasmid berbentuk double stranded circular DNA dimana memiliki panjang antara $2-3 \mathrm{~kb}$, dimana mengkode $10 \%$ dari kromosom sel induknya. Transfer gen resisten melalui plasmid lebih efektif dari mutasi gen kromosom, dimana banyak plasmid yang mengkode untuk resistensi terhadap beberapa golongan antibiotik (cephalosporin, fluoroquinolon, dan aminoglykosida), logam berat (merkuri, cadmium, perak) dan factor virulesi juga mempengaruhi resistensi terhadap antibiotik dengan konsentrasi lethal. ${ }^{11}$

Kelompok enzim CTX menyebabkan resistensi terhadap antibiotik melalui mekanisme hidrolisis terhadap komponen tertentu antibiotik, khususnya pada antibiotik golongan beta-laktam. Dalam penelitian di RSUP Sanglah, prevalensi kelompok gen bla CTXM yang ditemukan pada Klebsiella pnumoniae mencapai $83,33 \% .^{12}$

Dari data hasil uji sensitifitas antibiotik menggunakan Vitex, didapatkan hasil bahwa isolat resisten lebih dari 2 jenis antibiotik dan bisa dikatakan bahwa isolat termasuk dalam Multi Drug Resistance (MDR). Dari hasil vitex juga didapatkan bahwa bakteri juga termasuk dalam Extended Spectrum Beta-Lactamase (ESBL). Extended Spectrume BetaLactamase (ESBL) sendiri merupakan enzim yang dapat menghidrolisis beta-lactam lebih baik dan lebih luas dibandingkan dengan resistensi antibiotik biasanya, sehingga membuat bakteri menjadi Multi Drug Resistace (MDR) yang menyebabkan infeksi lebih sulit untuk diobati dan membutuhkan waktu yang lebih lama (Asma, 2006). Dan hasil ini sebenarnya sudah dikonfirmasi dari awal dimana semua sampel membawa gen CTX namun tidak aktif sehingga pengecekan fenotip, bakteri hanya resisten terhadap antibiotik ampicillin saja. Dengan pemberian antibiotik yang tidak rasional, maka mekanisme pertahanan dari bakteri tersebut akan mengaktifkan gen CTX agar dapat bertahan hidup dengan kondisi penambahan cefotaxime dan menjadikan bakteri termasuk dalam Extended Spectrum BetaLactamase (ESBL). Terdapat lebih dari 200 macam ESBL yang ditemukan dan diidentifikasi di dunia. ESBL umumnya dikode oleh plasmid dan dapat ditransfer melalui pertukaran plasmid atau transposon dan enzim ini banyak ditemukan pada E.coli, K.pneumoniae, dan P.mirabilis. ${ }^{13}$

Menurut penelitian Pelczar tahun 2006, terbentuknya resistensi dapat dikurangi dengan cara:

- Mencegah pemakaian antibiotik tanpa pembedaan pada kasus - kasus yang tidak membutuhkannya,

- Menghentikan penggunaan antibiotik pada infeksi biasa atau sebagai obat luar

- Menggunakan antibiotik yang tepat pula agar infeksi cepat sembuh

- Menggunakan antibiotik yang lain bila ada tanda - tanda bahwa suatu organisme akan menjadi resisten terhadap antibiotik yang digunakan semula. ${ }^{6}$

Dari penelitian ini diduga isolat K.pneumoniae yang didapatkan dari Instalasi Mikrobiologi Klinik RSUP Sanglah yang memiliki resistensi terhadap antibiotik golongan ampicillin cenderung memiliki gen pengkode ESBL, sehingga pemakian obat yang kurang tepat atau tidak rasional akan langsung bedampak dalam pengaktifan gen ESBL yang menyebabkan infeksi lebih parah dengan bertambahnya lebih banyak resistensi terhadap jenis antibiotik lain atau biasa di sebut Multi Drug Resistant (MDR). 


\section{SIMPULAN}

Adapun simpulan berdasarkan hasil dan pembahasan yang telah dipaparkan yaitu treatment ceftaxime konsentrasi sublethal dapat menyebabkan Multi Drug Resisten pada kuman Klebsiella pneumoniae.

\section{DAFTAR PUSTAKA}

1. Niyogi, S. K., 2005, Shigellosis, The Journal of Microbiology, 43 (2), 133-143.

2. Tumbarello $\mathrm{M}$ et al. 2007. Predictors of moratality in patient with bloodstream infection caused by extended-spectrum-beta-lactamase-producing Enterobacteriaceae: Importance of inadequate initial antimicrobial treatment. Antimicrobial Agents and Chemotherapy, 51, 1987 - 1994

3. Johann P and Kevin B. 2008. Extended-spectrum $\beta$-lactamse-producing Enterobacteriaceae: an emerging public-health concern. Lancert Infect Dis 8:159-66

4. Asma M. 2006. Extended-Spectrum Beta-Lactamases (ESBLs) : A Global Problem. Department of Microbiology, Armed ForcesHospital, Ridyadh. Saudi Arabia

5. Fatmawati N N D, Adi Tarini N M, Sri Budayanti N N, Yuliandari Putu. 2015. Molecular characterization of Extended-spectrum $\beta$-lactamases-producing Klebsiella pneumoniae isolated from clinical specimens at a tertiary-referral hospital in Denpasar, Bali, Indonesia. Advance Science Letter Vol 21:p219-221

6. Dewi Khanifah Fitria, 2010, Skrining Bakteri Penghasil Extended Spectrum Beta Lactamase (ESBLs) Pada Kasus Infeksi Saluran Kemih Terkait Kateterisasi Di RSUD Padang Arang Boyolali, Skripsi Fakultas Kedokteran Universitas Sebelas Maret, Surakarta
7. Kee, J. L. dan Evelyn, R. H. 1996. Farmakologi : Pendekatan proses Keperawatan. Cetakan I. Jakarta. Penerbit Buku Kedokteran EGC. Hal. 305

8. Baharirama Made Virgo dan Ayu Artini I Gusti, 2013, Pola Pemberian Antibiotika Untuk Pasien Community Acquired Pneumonia Anak di Instalasi Rawat Inap RSUD Buleleng Tahun 2013, Fakultas Kedokteran Universitas Udayana.

9. Thenmozhi S. Moorthu K. Suhershkumar B. T. Suresh M, 2014, Antibiotic Resistance Mechanism of ESBL Producing Enterobacteriacea in Clinical Field : A Review, International Journal Of Pure and Applied Bioscience 2(3): 207-226

10. Guerin, E. Cambray, G. Sanchez-Alberola, N. Campoy, S. Erill, I. Da Re S, et al.,2009, The SOS response controls integron recombination. Science, 324: 1034-7

11. Hawkey, P, 2008, Molecular epidemiology of clinical significant antibiotic resistance genes. Br. J.Pharmacol. 153: 406-13

12. Apriliani NP Eka Umarista dan Pinatih K Januartha Putra, 2017, Prevalensi Kelompok Gen blaCTXM pada Klebsiella pnuemoniae Di Rumah Sakit Umum Pusat Sanglah Denpasar, Fakutas Kedokteran Universitas Udayana

13. Bradford PA. 2001. Extended-spectrum beta-lactamases in the 21st century: characterization, epidemiology, and detection of this important resistance threat. Clin Microbiol Rev. 14(4):933-51.

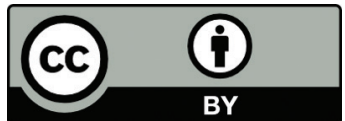

This work is licensed under a Creative Commons Attribution 